\title{
The Self-Evidence of Human Rights
}

\author{
Origins and Limits of an Idea
}

\author{
Bardo Fassbender
}

\begin{abstract}
We hold these truths to be self-evident, that all men are created equal, that they are endowed by their Creator with certain unalienable Rights, that among these are Life, Liberty and the pursuit of Happiness.
\end{abstract}

The Declaration of Independence, 4 July 1776

all eyes are opened, or opening to the rights of man.

Thomas Jefferson, 24 June $1826^{1}$

It is a pleasure to comment on Lynn Hunt's vivid reconsideration of a truly crucial moment in the history of human rights when in North America and in France for the first time a 'self-evidence' of certain rights of 'all men' was claimed in constitutional discourse and documents, and a fundamental shift occurred in the explanation of human rights 'from a religious framework toward a secular one': 'Self-evidence is the human replacement for God-given truths.'2

Drawing on her widely acclaimed and influential book Inventing Human Rights, of $2007,{ }^{3}$ and using new data gathered by n-gram analysis, Professor Hunt first leads us back to the British colonies in North America on the verge of their separation from Great Britain, to revolutionary France, and to the writings of John Locke in which the notion of 'self evident truths' played an important role. She next puts the question 'why the notion of self-evident universal rights with foundational political status was persuasive to people at the time, ${ }^{4}$ finding some of the answers in the language of human rights as it appeared in eighteenth-century novels and newspapers in the Anglophone and Francophone worlds. In the last section of her

1 Thomas Jefferson, Letter to the Mayor of Washington, D.C., Roger C. Weightman, 24 June 1826, in The Papers of Thomas Jefferson <http://founders.archives.gov/documents/Jefferson/98-01-02-6179> accessed 31 January 2019. Jefferson died on 4 July 1826.

2 See Lynn Hunt, 'Humanity and the Claim to Self-Evidence', ch. 1 in this volume, 41 (hereafter Hunt, 'Self-Evidence').

${ }^{3}$ See Lynn Hunt, Inventing Human Rights: A History (WW Norton \& Co. 2007) (hereafter Hunt, Inventing Human Rights). A paperback edition was published in 2008.

4 See Hunt, 'Self-Evidence' (n. 2) 42. 
chapter, Lynn Hunt addresses the limitations of the enjoyment of civil and political rights in the colonies and the independent United States as well as in postrevolutionary France-limitations which often amounted to a complete exclusion of rights, and which applied to a majority of the population: 'Eighteenth-century men had to work very hard at simultaneously demanding rights and universal equality while also maintaining insurmountable barriers that could keep out children, women, slaves, servants, and men without property.5

Having read Lynn Hunt's fascinating account of the events and debates in North America and France, I wanted to know more about how exactly the notion of 'selfevident truths', so central to Professor Hunt's line of reasoning, found its way into the Declaration of Independence of 1776. Was it Benjamin Franklin's idea, ${ }^{6}$ or rather introduced by Jefferson himself in the course of drafting the Declaration? What does it mean, and why does it matter, that Jefferson's original expression 'sacred \& undeniable' was replaced with 'self-evident'? Accordingly, the first part of my present comments (which focus on North America) is devoted to the Declaration's drafting history and to the meaning and importance of the claim to 'self-evidence' in the Declaration of Independence. In a much briefer second part, I then return to Lynn Hunt's analysis of the 'limitations' of the actual enjoyment of rights in eighteenthcentury North America and France, adding a few remarks regarding the treatment of the 'Indians' and of the slave trade in the Declaration. The third and last part of my comments deals with the importance, or rather unimportance, of the notion of the self-evidence of human rights in the present age. I argue that, against the expectations of his time, Jefferson's idea of self-evidence failed to find general recognition, so that we must search for a new credible foundation of universal human rights.

\section{THE ORIGINS OF SELF-EVIDENCE}

On 7 June 1776, Richard Henry Lee, in accordance with instructions from the Virginia Convention, proposed to the Continental Congress in Philadelphia to adopt a resolution 'That these United Colonies are, and of right ought to be, free and independent States, that they are absolved from all allegiance to the British Crown, and that all political connection between them and the State of Great Britain is, and ought to be, totally dissolved. ${ }^{7}$ On 11 June, consideration of the Lee Resolution was postponed, and Congress recessed for three weeks. Before receding, and expecting

5 Ibid, 49.

${ }^{6} \mathrm{Ibid}, 42$ (referring to Walter Isaacson, see n. 22).

7 For this and the following, see 'The Declaration of Independence: A History' (no author given) $<$ http://www.archives.gov/founding-docs/declaration-history> accessed 31 January 2019. See also Julian P Boyd, The Declaration of Independence: The Evolution of the Text as Shown in Facsimiles of Various Drafts by its Author, Thomas Jefferson (Princeton University Press 1945) 7-16 (hereafter Boyd, Declaration); Pauline Maier, American Scripture: Making the Declaration of Independence (Alfred A Knopf 1997), ch. III: Mr. Jefferson and His Editors, 97-153 (hereafter Maier, American Scripture); Gerard W Gawalt, 'Drafting the Declaration' in Scott Douglas Gerber (ed.), The Declaration of Independence: Origins and Impact (CQ Press 2002) 1. 
an adoption of the resolution after the break, Congress appointed a Committee of Five to draft a statement that would present to the world the colonies' case for independence. The committee consisted of John Adams, Roger Sherman, Benjamin Franklin, Robert R Livingston, and Thomas Jefferson. In 1823, Jefferson remembered that the other members of the committee 'unanimously pressed on myself alone to undertake the draught. I consented; I drew it; but before I reported it to the committee I communicated it separately to Dr. Franklin and Mr. Adams requesting their corrections .... I then wrote a fair copy, reported it to the committee, and from them, unaltered to the Congress.' Jefferson's account reflects three stages in the making of the Declaration: the original document written by Jefferson; the changes made to that document by Franklin and Adams, resulting in the version submitted by the Committee of Five to the Congress on 28 June; and the version that was eventually adopted by Congress on 4 July 1776.

The Declaration consists of five distinct parts: an introduction; a preamble; a body, which can be divided into two sections (the indictment of King George III, and the denunciation of the British people); and a conclusion. The statement we are concerned with here opens the preamble which 'outlines a general philosophy of government that makes revolution justifiable, even meritorious.'

When drafting the Declaration's preamble, Thomas Jefferson very likely was aware of two very recent documents, namely George Mason's draft of the Virginia Bill of Rights (of ca. 20-26 May 1776, published on 6 June 1776), and the Virginia Declaration of Rights, adopted on 12 June 1776. The pertinent part of Mason's draft reads as follows:

A Declaration of Rights, made by the Representatives of the good People of Virginia, assembled in full Convention; and recommended to Posterity as the Basis and Foundation of their Government

That all men are born equally free and independent, and have certain inherent natural Rights, of which they can not, by any compact, deprive or divest their Posterity; among which are the Enjoyment of Life and Liberty, with the Means of acquiring and possessing Property, and pursuing and obtaining Happiness and Safety.

That Power is, by God and Nature, vested in, and consequently derived from the People, that Magistrates are their Trustees and Servants, and at all times amenable to them. ${ }^{9}$

With few changes, that draft was adopted on 12 June 1776 by the fifth Virginia Convention at Williamsburg as the Virginia Declaration of Rights, the title and first two sections of which have the following wording:

\footnotetext{
${ }^{8}$ See Stephen E Lucas, 'The Stylistic Artistry of the Declaration of Independence' <http://www. archives.gov/founding-docs/stylistic-artistry-of-the-declaration> accessed 31 January 2019 (hereafter Lucas, 'Stylistic Artistry').

${ }^{9}$ Boyd, Declaration (n. 7) Doc. I (facsimile), also available at <http://www.gunstonhall.org/ georgemason/human_rights/vdr_first_draft.html> accessed 31 January 2019.
} 
A DECLARATION OF RIGHTS made by the Representatives of the good people of VIRGINIA, assembled in full and free Convention; which rights do pertain to them and their posterity, as the basis and foundation of Government.

1. That all men are by nature equally free and independent, and have certain inherent rights, of which, when they enter into a state of society, they cannot, by any compact, deprive or divest their posterity; namely, the enjoyment of life and liberty, with the means of acquiring and possessing property, and pursuing and obtaining happiness and safety.

2. That all power is vested in, and consequently derived from, the people; that magistrates are their trustees and servants, and at all times amenable to them. ${ }^{10}$

Neither text contains a reference to 'self-evident truths', and instead of the later Declaration's phrase 'certain unalienable Rights', use the expressions 'certain inherent natural Rights' and 'certain inherent rights', respectively. According to Julian Boyd, the similarity of the texts is a similarity of ideas: 'Jefferson and Mason were both dealing with the concept of natural, inherent rights and on this subject both appealed, as all men of the day did, to Locke and other exponents of the idea of the social compact, the inviolability of rights, the trusteeship nature of government, and the right of revolution. ${ }^{11}$ Jefferson himself later emphasized that it was the object of the Declaration '[n] ot to find out new principles, or new arguments never before thought of ... but to place before mankind the common sense of the subject, in terms so plain and firm as to command their assent. ${ }^{12}$

Jefferson's so-called 'Rough Draft' of the Declaration, which has survived in his Papers in the Library of Congress, represents the text as Jefferson submitted it to the other members of the Committee of Five, together with all corrections, additions, and deletions made by the Committee, and by the Congress, ${ }^{13}$ that way serving Jefferson as a complete record of the drafting process. Very likely, the 'Rough Draft' was preceded by earlier compositions. ${ }^{14}$

According to the 'Rough Draft', Jefferson first wrote: 'We hold these truths to be sacred \& undeniable.' In the draft, the words 'sacred \& undeniable' are crossed out, and 'self-evident' is written in above the line:

We hold these truths to be sacred \& undeniable; self-evident; that all men are created equal \&independant; that from that equatereation they derive rights some-

${ }^{10}$ For the full text, see <http://www.gunstonhall.org/georgemason/human_rights/vdr_final.html> accessed 31 January 2019; see also James Madison, 'Notes of the Virginia Convention, May-June, 1776' in Library of Congress, James Madison Papers <https://www.loc.gov/exhibits/creating-the-unitedstates/battle-joined.html\#obj15> accessed 31 January 2019.

11 Boyd, Declaration (n. 7) 15.

12 Thomas Jefferson, Letter to Henry Lee, 8 May 1825, quoted in David Armitage, The Declaration of Independence: A Global History (Harvard University Press 2007) 21 (hereafter Armitage, Declaration).

${ }^{13}$ Boyd, Declaration (n. 7) 40.

14 Ibid, 25-7. 
of wich are they are endowed by their creator with certain [inherent $\&$ ] inalienable rights; that among wieh these are the preservation of life, \& liberty, \& the pursuit of happiness; that to secure these ends rights, governments are instituted among men, deriving their just powers from the consent of the governed; that whenever any form of government shall becomes destructive of these ends, it is the right of the people to alter or to abolish it, \& to institute new government, laying it's foundation on such principles \& organising it's powers in such form, as to them shall seem most likely to effect their safety \& happiness. ${ }^{15}$

In his seminal book about the Declaration of Independence, the historian Carl Becker asked: 'Was this correction [the replacement of 'sacred \& undeniable' with 'self-evident'] made by Jefferson in process of composition? Or by the Committee of Five? Or by Congress? There is nothing in the Rough Draft itself to tell us. ${ }^{\text {'i6 }}$

In Boyd's reconstruction, the 'original rough draft', as he called it, had approximately the following wording when it was submitted by Jefferson to Franklin and Adams:

We hold these truths to be sacred \& undeniable; that all men are created equal \& independant, that from that equal creation they derive rights inherent $\&$ inalienable, among which are the preservation of life, \& liberty, \& the pursuit of happiness; that to secure these ends, governments are instituted among men, deriving their just powers from the consent of the governed; that whenever any form of government shall become destructive of these ends, it is the right of the people to alter or to abolish it, \& to institute new government, laying it's foundation on such principles \& organizing it's power in such form, as to them shall seem most likely to effect their safety $\&$ happiness. ${ }^{17}$

In an early copy of the draft, made by John Adams sometime between 11 and 21 June $1776,{ }^{18}$ the expression 'self evident' is already there:

We hold these Truths to be self evident; that all Men are created equal and independent; that from that equal Creation they derive Rights inherent and unalienable; among which are the Preservation of Life, and Liberty, and the Pursuit of Happiness; ... 19

15 Ibid, Doc. V (facsimile of the original kept in the Library of Congress).

16 Carl Becker, The Declaration of Independence: A Study in the History of Political Ideas (2nd edn, Alfred A Knopf 1942) 140 (hereafter Becker, Declaration).

17 See Boyd, Declaration (n. 7) 19; Julian P Boyd (ed.), The Papers of Thomas Jefferson, vol. 1, 1760-76 (Princeton University Press 1950) 423-8 <https://founders.archives.gov> accessed 31 January 2019. See also Becker, Declaration (n. 16) 141, 142: 'The Rough Draft, as it probably read when Jefferson first submitted it to Franklin'.

18 See Boyd, Declaration (n. 7) 40.

19 Ibid, Doc. IV (facsimile). 
Boyd wrote about the replacement of 'sacred \& undeniable' with 'selfevident': 'This famous and altogether felicitous change has been attributed both to Franklin and to Jefferson. Such feeling as it exhibits for precisely the right word is quite Franklinian in character, but the handwriting in the phrase 'self-evident' bears the appearance of being equally Jeffersonian.... If my interpretation of these alterations is correct, ... then it appears that Franklin had made no changes in the text when Adams made his copy of the Rough Draft'-so that Jefferson, rather than Franklin, is responsible for introducing the term 'self-evident. ${ }^{20}$ As we shall see, ${ }^{21}$ the omission of the word 'sacred' gave the entire preamble of the Declaration a secular character, basing the proclaimed rights entirely on reason instead of religion or (a Christian) God's will. The remaining 'undeniable' could easily be replaced with the stronger expression 'self-evident' which was equally familiar to contemporary readers. These arguments support Jefferson's authorship of 'selfevident', which is also assumed by the more recent literature on the Declaration. ${ }^{22}$

Further changes were made before the Committee approved the Declaration and reported it to Congress. By using certain copies made by Jefferson (for Richard Henry Lee, for Madison, and for George Wythe) 'in comparison with the Rough Draft as it stood after Adams had made his copy, it is possible to arrive at the number of changes made before the Declaration went to Congress. ${ }^{23}$ In that stage, the phrase 'from that equal creation they derive rights' was changed to 'they are endowed by their creator with', while the phrase 'equal rights some of which are' was struck out in the process of making the correction, and the words 'rights; that' were inserted between the lines of writing after 'inalienable. ${ }^{24}$

Finally, Congress, discussing the draft of the Declaration on 3 and 4 July, changed 'inherent \&' to 'certain', and 'inalienable' to 'unalienable.25 Accordingly, the text in

${ }^{20}$ Ibid, 22 and 24. Becker, too, attributes the change to Jefferson; see Becker, Declaration (n. 16) 198.

21 See text accompanying n. 29.

${ }^{22}$ See Michael P Zuckert, 'Self-Evident Truth and the Declaration of Independence' (1987) 49 Review of Politics 319, 328 (hereafter Zuckert, 'Self-Evident Truth'); Allen Jayne, Jefferson's Declaration of Independence: Origins, Philosophy and Theology (University Press of Kentucky 1998) 110 (hereafter Jayne, Jefferson's Declaration); Maier, American Scripture (n. 7) 133, 136 left the question undecided, while Isaacson in his biography of Franklin claimed the latter's authorship: 'He [Franklin] crossed out, using the heavy backslashes that he often employed, the last three words of Jefferson's phrase "We hold these truths to be sacred and undeniable" and changed them to the words now enshrined in history: "We hold these truths to be self-evident"'. See Walter Isaacson, Benjamin Franklin: An American Life (Simon \& Schuster 2003) 312. However, the same kind of backslashes was used by Jefferson in his copy of A Summary View of the Rights of British America (see n. 34) on pp. 7, 8, 12, and 17, so that it cannot be seen as Franklin's peculiarity. In fn. 34 (on p. 547 of his book), meant to verify his quoted statement, Isaacson confuses the 'original rough draft' as reconstructed by Boyd with Jefferson's 'rough draft' preserved in the Library of Congress.

${ }^{23}$ Boyd, Declaration (n. 7) 28.

24 Ibid, 29. See also Becker, Declaration (n. 16) 161: 'The Rough Draft as it probably read when Jefferson made the "fair copy" which was presented to Congress as the report of the Committee of Five.'

25 Boyd, Declaration (n. 7) 32. According to Boyd, ibid, the latter change 'may possibly have been made by the printer rather than at the suggestion of Congress... Both forms were apparently current in the eighteenth century.' 
the copy of the adopted Declaration made by Jefferson for Richard Henry Lee (between 4 and 10 July 1776), reads as follows:

We hold these truths to be self-evident; that all men are created equal; that they are endowed by their Creator with inherent and inalienable rights [on the left margin: certain unalienable rights]; that among these are life, liberty, and the pursuit of happiness; that to secure these rights, governments are instituted among men, deriving their just powers from the consent of the governed; that whenever any form of government becomes destructive of these ends, it is the right of the people to alter or to abolish it, and to institute new government, laying it's foundation on such principles and organising it's powers in such form, as to them shall seem most likely to effect their safety and happiness. ${ }^{26}$

The method of underlining certain words and of placing others in the margin was explained by Jefferson at the beginning of his copy of the Declaration made for James Madison: 'as the sentiments of men are known not only by what they receive, but what they reject also, I will state the form of the declaration as originally reported [by the Committee of Five to Congress]. the parts struck out by Congress shall be distinguished by a black line drawn under them, \& those inserted by them shall be placed in the margin or in a concurrent column., ${ }^{27}$

According to Stephen Lucas, the first half sentence of the Declaration's preamble ('We hold these truths to be self-evident') is the opening sequence of five propositions that build upon one another:

Proposition 1: All men are created equal.

Proposition 2: They (all men) are endowed by their creator with certain unalienable rights.

Proposition 3: Among these rights are life, liberty, and the pursuit of happiness.

Proposition 4: To secure these rights, governments are instituted among men.

Proposition 5: Whenever a form of government becomes destructive of this end (securing man's unalienable rights), it is the right of the people to alter or abolish it. $^{28}$

But is,for that sequence of arguments, the phrase 'We hold these truths to be selfevident' really necessary? Does it add something to the set of propositions? Would

${ }^{26}$ Ibid, Doc. VI (facsimile). See also Becker, Declaration (n. 16) 174-5, and the copy made by Jefferson for James Madison (sent to Madison on 1 June 1783; Boyd, Declaration (n. 7) Doc. VIII [facsimile]): 'We hold these truths to be selfevident [sic]; that all men are created equal; that they are endowed by their Creator with (inherent \&) inalienable rights [on the left margin: certain]; that among these are life, liberty, \& the pursuit of happiness; ....

27 Boyd, Declaration (n. 7) Doc. VIII, 2.

28 Lucas, 'Stylistic Artistry' (n. 8). 
the Declaration's preamble have a different meaning if the phrase was missing, and the preamble would only say, in the style of the Virginia Declaration of Rights: ${ }^{29}$ 'All men are created equal, they are endowed by their Creator with certain unalienable Rights' (and so forth)?

Indeed, the 'added value' of the phrase lies in what Lynn Hunt concisely calls the 'claim to self-evidence' of fundamental human rights. 'Self-evident' means 'evident by itself; requiring no proof or explanation; obvious, axiomatic. ${ }^{30}$ The concept of self-evidence allowed the authors of the Declaration to introduce the rights to life, liberty, and the pursuit of happiness as a given, as something which does not need to be explained or deduced from something else, and which does not need a foundation in the form of a specific religious or philosophical belief system. ${ }^{31}$ That idea of the indisputable existence of certain human rights would not have been conveyed by Jefferson's original expression 'We hold these truths to be sacred \& undeniable, ${ }^{32}$ the adjective 'sacred' being too strongly associated with (Christian) religion (as in 'sacred book', 'sacred blood', 'sacred heart', or 'sacred music'). (In the Declaration's introduction, it is true, Jefferson also referred to the Laws of Nature and of Nature's God' as providing a right to a 'separate and equal station' of the American people, but that reasoning is not used in the following paragraph as an explanation of the existence of 'certain unalienable Rights. ${ }^{33}$ )

Jefferson's secularism-new in comparison with his earlier writings ${ }^{34}$-was nevertheless to some extent diluted by the Committee of Five which introduced the word 'Creator' into the Declaration's preamble, and by Congress which added

${ }^{29}$ See text accompanying n. 10.

${ }^{30}$ See The Oxford English Dictionary (3rd edn, Oxford University Press 2018).

31 There is a rich literature on the philosophical meaning and background of the term 'self-evident' which I can only mention here. The debate mainly concerns, in the words of Sanford Levinson, 'SelfEvident Truths in the Declaration of Independence' (1979) 57 Texas Law Review 847, 851: 'the relative importance of John Locke and several Scottish philosophers, particularly Francis Hutcheson, David Hume, and Thomas Reid, upon the Jefferson of 1776'. See, in particular, Morton White, The Philosophy of the American Revolution (Oxford University Press 1978); Garry Wills, Inventing America: Jefferson's Declaration of Independence (Doubleday \& Co. 1978) 181-92; Zuckert, 'Self-Evident Truth' (n. 22); Jayne, Jefferson's Declaration (n. 22) particularly ch. 6; Owen Anderson, The Declaration of Independence and God: Self-Evident Truths in American Law (Cambridge University Press 2015).

${ }^{32}$ See text accompanying $n .17$.

33 That difference was disregarded by Bentham in his critique of the Declaration of 1776: 'In this preamble however it is, that they attempt to establish a theory of Government; a theory, as absurd and visionary, as the system of conduct in defence of which it is established, is nefarious... They are about "to assume", as they tell us, "among the powers of the earth, that equal and separate station to which" - they have lately discovered- "the laws of Nature, and of Nature's God entitle them"... If to what they now demand they were entitled by any law of God, they had only to produce that law, all controversy was at an end. Instead of this, what do they produce? What they call self-evident truths.' Jeremy Bentham, An Answer to the Declaration of the American Congress (London 1776), reproduced in Armitage,
Declaration (n. 12) 173-4.

${ }^{34}$ In his 1774 essay A Summary View of the Rights of British America, Jefferson had still referred to 'those rights which God and the laws have given equally and independently to all, and had closed his resolutions by saying: "The God who gave us life gave us liberty at the same time; the hand of force may destroy, but cannot disjoin them.' See Thomas Jefferson, A Summary View of the Rights of British America. Set Forth in Some Resolutions Intended for the Inspection of the Present Delegates of the People of 
references to 'the Supreme Judge of the world' and 'divine Providence' to the text of the conclusion. ${ }^{35}$

However, the Declaration does not say: 'These truths are self-evident, that all men are created equal, that they are endowed by their Creator with certain unalienable Rights ... ' Instead, it says 'We hold these truths to be self-evident ...' Emphasizing the first word ('We hold'), one can see that phrase as modifying the following propositions: The propositions are subjectivized, and thereby their qualification as 'truths' is relativized. 'We hold' implies that not necessarily everybody else holds, or must hold, the same opinion. And who is 'we'? It is, as stated in the very first words of the Declaration, 'the thirteen united States of America' and, more exactly, as it is said in the Declaration's last paragraph, 'we, the Representatives of the United States of America, in General Congress, Assembled'. To us, the authors of the Declaration seem to say, the following propositions are self-evident truths, and we hope to convince a 'candid world' to share this view. ${ }^{36}$

\section{II. 'ALL MEN'? THE LIMITS OF SELF-EVIDENCE}

There is, as Lynn Hunt convincingly explains in her chapter's section entitled 'Limitations', a contradiction between the Declaration's claim to a self-evidence of universal human rights ('all men are created equal', 'they are endowed ... with certain unalienable Rights' ${ }^{37}$ and the exclusion, in the law not only of the American colonies but also of the independent United States, of women, children, slaves, and servants from most civil and political rights (and of slaves even from the emphatically proclaimed rights to life, liberty, and the pursuit of happiness). In the Declaration, the political philosophy of universal rights was used to justify the separation of the colonies from Great Britain but, it seems, otherwise not taken seriously. ${ }^{38}$

Virginia now in Convention. By a Native, and Member of the House of Burgesses (Clementina Rind 1774) 5 and 23, respectively <https://www.wdl.org/en/item/117/> (facsimile) and <https://founders.archives.gov/documents/Jefferson/01-01-02-0090> accessed 31 January 2019 (hereafter Jefferson, Rights of British America).

35 See Boyd, Declaration (n. 7) 29 and 34.

36 See also Zuckert, 'Self-Evident Truth' (n. 22) 322 and 329: '[T]he "we hold" emphasizes the premises of the argument as particularly the property of the Americans, and not necessarily shared in the opinions of the rest of mankind... [T] he truths announced in the Declaration are not in fact selfevident, nor are they pronounced to be. They are rather to be held as if self-evident within the political community dedicated to making them effective. The truths must serve as the bedrock or first principles of all political reasoning in that regime.' (Emphasis added).

${ }^{37}$ Emphasis added.

38 But see Abraham Lincoln, speaking in 1857: 'They [the authors of the Declaration] meant to set up a standard maxim for free society, which should be familiar to all, and revered by all; constantly looked to, constantly labored for, and even though never perfectly attained, constantly approximated .... The assertion that "all men are created equal" was of no practical use in effecting our separation from Great 
One group of people which in the Declaration itself is clearly excluded from the rights attributed to 'all men' is 'the merciless Indian Savages'. In the last paragraph of the indictment of George III, it is said: 'He [the King] has excited domestic insurrections amongst us, and has endeavoured to bring on the inhabitants of our frontiers, the merciless Indian Savages, whose known rule of warfare, is an undistinguished destruction of all ages, sexes and conditions. ${ }^{39}$ An accusation with an almost identical wording was already included in Jefferson's 'First Ideas' on the Virginia Constitution..$^{40}$ Jefferson clearly made an effort to justify that exclusion of the Native Americans from 'all men', in the first place by calling them 'savages', and further by emphasizing their allegedly cruel, that is, inhuman, warfare against the settlers, by which they have separated themselves from humanity.

On the other hand, Jefferson's draft included an indictment of the King because of the slave trade, calling that trade a 'cruel war against human nature itself, violating it's most sacred rights of life \& liberty in the persons of a distant people', namely the Africans:

$[\mathrm{H}] \mathrm{e}$ has waged cruel war against human nature itself, violating it's most sacred rights of life \& liberty in the persons of a distant people, who never offended him, captivating and carrying them into slavery in another hemisphere, or to incur miserable death in their transportation thither. This piratical warfare, the opprobrium of infidel powers, is the warfare of the Christian king of Great Britain, determined to keep open a market where M E N should be bought \& sold; he has prostituted his negative for suppressing every legislative attempt to prohibit or to restrain this execrable commerce, and that this assemblage of horrors might want no fact of distinguished die, he is now exciting those very people to rise in arms among us, and to purchase that liberty of which he has deprived them, by murdering the people upon whom $h e$ also obtruded them: thus paying off former crimes committed against the liberties of one people, with crimes which he urges them to commit against the lives of another. ${ }^{41}$

That paragraph of the draft was only deleted by Congress, ${ }^{42}$ in deference to the Southern colonies ${ }^{43}$ but also because the delegates realized that they could hardly

Britain; and it was placed in the Declaration, not for that, but for future use.' Speech on the Dred Scott Decision at Springfield, Illinois, 26 June 1857, in Abraham Lincoln, Speeches and Writings 1832-1858 (Don E Fehrenbacher, ed., The Library of America 1989) 390, 398-9.

39 Emphasis added.

40 See 'First Draft by Jefferson' (of the Virginia Constitution), before 13 June 1776, in Julian P Boyd (ed.), The Papers of Thomas Jefferson, vol. 1, 1760-76 (Princeton University Press 1950) 337 et seq, also available at <http://founders.archives.gov> accessed 31 January 2019.

${ }_{41}$ See Copy made by Jefferson for Richard Henry Lee; Boyd, Declaration (n. 7) Doc. VI (facsimile).

42 See Boyd, Declaration (n. 7) 31, 33.

43 Jefferson recorded in his 'Notes' that the clause 'reprobating the enslaving the inhabitants of Africa, was struck out in complaisance to S. Carolina \& Georgia, who had never attempted to restrain the importation of slaves \& who on the contrary still wished to continue it. Our northern brethren 
convincingly charge the King alone with a slave trade in which the colonists actively participated and from which they benefitted. ${ }^{44}$ Jefferson had already formulated a similar charge against the King in a set of instructions for the Virginia delegates to the first Continental Congress, published in July 1774 as A Summary View of the Rights of British America. ${ }^{45}$

\section{THE SHATTERED BELIEF IN THE SELF-EVIDENCE OF HUMAN RIGHTS}

The 'we' of Jefferson's 'we hold these truths' could rightfully claim to stand not only for the representatives of the thirteen United States but for a broad majority of educated people in Europe and North America in the second half of the eighteenth century. As Pauline Maier wrote in her book about the Declaration, 'the sentiments Jefferson eloquently expressed were ... absolutely conventional among Americans of his time'46 -and also in that sense 'self-evident'. In other words, the 'we' was conceived of as being in harmony with the spirit of the age, with the thinking of all righteous, honest, and virtuous men and women; and reason would sooner or later enlighten those who had not yet discovered the truth.

However, in the meantime, and in particular in the course of the twentieth century, that Enlightenment belief in the self-evidence of human rights has been shattered. War, genocide, and systematic violations of human rights make it impossible still to assert that the existence of fundamental human rights is obvious to all people endowed with reason. The 'we' of the Declaration of 1776 has not become universal. In 1948, the member states of the United Nations deemed it necessary to adopt the

also, I believe, felt a little tender under those censures; for tho' their people have very few slaves themselves, yet they had been pretty considerable carriers of them to others.' See Becker, Declaration (n. 16) 171-2; Boyd, Declaration (n. 7) 37. For the entire text, see Barry Alan Shain (ed.), The Declaration of Independence in Historical Context (Liberty Fund 2014) 501-2.

44 See also Maier, American Scripture (n. 7) 146-7: 'Some people recognized the contradiction and were ready to move toward greater consistency between principle and practice, but so monumental a change as the abolition of slavery could not be accomplished in a moment. For the time being, it was wise at least not to call attention to the persistence of the slave trade and to the anomaly of American slavery.'

45 See Jefferson, Rights of British America (n. 34) 16 et seq: 'The abolition of domestic slavery is the great object of desire in those colonies, where it was unhappily introduced in their infant state. But previous to the enfranchisement of the slaves we have, it is necessary to exclude all further importations from Africa; yet our repeated attempts to effect this by prohibitions, and by imposing duties which might amount to a prohibition, have been hitherto defeated by his majesty's negative: Thus preferring the immediate advantages of a few African corsairs to the lasting interests of the American states, and to the rights of human nature, deeply wounded by this infamous practice.' In his personal copy, preserved in the Library of Congress, Jefferson replaced the word 'African' in 'African corsairs' with 'British'. See the facsimile of the copy <https://www.wdl.org/en/item/117/> accessed 31 January 2019.

${ }^{46}$ See Maier, American Scripture (n. 7) 135. 
Convention on the Prevention and Punishment of the Crime of Genocide. ${ }^{47}$ In the preamble of the Convention, it was rightly said that 'at all periods of history genocide has inflicted great losses on humanity', including, unfortunately, the periods following the proclamation of the Declaration of Independence.

Fifty years after the adoption of the Convention against Genocide, states agreed on the Rome Statute of the International Criminal Court, ${ }^{48}$ establishing a permanent court with 'jurisdiction over persons for the most serious crimes of international concern' (Article 1 of the Statute), namely the crime of genocide, crimes against humanity, war crimes, and the crime of aggression (Article 5 of the Statute). It is undeniably true what the states parties to the Statute declared in the Statute's preamble: 'during this century millions of children, women and men have been victims of unimaginable atrocities that deeply shock the conscience of humanity'.

In that situation, it is impossible to content ourselves with the fact of the discovery of a 'self-evident truth' in the eighteenth century. One could also say that Jefferson's idea of self-evidence turned out to be an illusion. The existence of fundamental human rights may be a truth, but that truth is not evident to everybody. The importance of fundamental human rights is not self-evident. Instead, such rights need to be understood, learned, accepted, and respected in order to become real. It is not enough to throw the spotlight of reason on such rights to make them work. Instead, human rights need a solid foundation.

In the world of today, such a foundation must be of a truly universal character. If there is a universal right to life, liberty, and the pursuit of happiness, we need to find forms of acceptance of such a right and of the underlying ideas and concepts in all parts and all cultures of the world. A serious effort to arrive at such a common understanding' of human rights was made early in the history of the United Nations when the Human Rights Commission drafted the Universal Declaration of Human Rights (UDHR). ${ }^{49}$ Eleanor Roosevelt, the chairperson of the Commission, spoke of a 'flow backwards and forwards of ideas and understanding. ${ }^{50}$ Unfortunately, the

47 Convention on the Prevention and Punishment of the Crime of Genocide (adopted 9 December 1948, entered into force 12 January 1951) 78 UNTS 277. In Article II of the Convention, genocide is defined as any of the following acts committed with intent to destroy, in whole or in part, a national, ethnical, racial or religious group, as such: (a) killing members of the group; (b) causing serious bodily or mental harm to members of the group; (c) deliberately inflicting on the group conditions of life calculated to bring about its physical destruction in whole or in part; (d) imposing measures intended to prevent births within the group; (e) forcibly transferring children of the group to another group. Of the vast literature on the Convention's genesis, I only mention the recent study by Douglas Irvin-Erickson, Raphaël Lemkin and the Concept of Genocide (University of Pennsylvania Press 2017) 152-96.

48 Rome Statute of the International Criminal Court (adopted 17 July 1998, entered into force 1 July 2002) 2187 UNTS 3.

49 GA Res. 217 A (III), 10 December 1948; (1948-9) UN Yearbook 535-7. The last paragraph of the preamble of the Declaration reads: 'Whereas a common understanding of these rights and freedoms is of the greatest importance for the full realization of this pledge [to achieve the promotion of universal respect for and observance of human rights and fundamental freedoms].'

50 See Eleanor Roosevelt, 'Writing the Universal Declaration of Human Rights' in Bardo Fassbender (ed.), Menschenrechteerklärung-Universal Declaration of Human Rights (Sellier European Law Publishers 2009) 31, 41. 
later universal human rights treaties reflected political compromise reached by the Western and the communist states rather than universal perceptions and concepts.

Today, new efforts to build and sustain a universal foundation of fundamental human rights are necessary, not only and not even primarily by states but rather by civil society, so that these rights, in the words of Lynn Hunt, continue 'to resonate with a broader public ${ }^{51}$-and this time not just in France and North America. One example of a civil society initiative working in that direction is the Projekt Weltethos (Global Ethic Project) initiated by the Swiss theologian and philosopher Hans Küng ${ }^{52}$ that tries to identify and to strengthen, across cultures and religions, 'a fundamental consensus on binding values, irrevocable standards, and personal attitudes. ${ }^{53}$ In that sense, the Project's 1993 'Declaration Toward a Global Ethic' said: 'We are convinced of the fundamental unity of the human family on Earth. We recall the 1948 Universal Declaration of Human Rights of the United Nations. What it formally proclaimed on the level of rights we wish to confirm and deepen here from the perspective of an ethic: The full realization of the intrinsic dignity of the human person, the inalienable freedom and equality in principle of all humans, and the necessary solidarity and interdependence of all humans with each other. ${ }^{54}$ And yet it will be impossible to recover the self-assurance with which in the summer of 1776 Thomas Jefferson and his fellows placed their trust in the selfevidence of rights of all men.

\section{Bibliography}

Anderson O, The Declaration of Independence and God: Self-Evident Truths in American Law (Cambridge University Press 2015)

Armitage D, The Declaration of Independence: A Global History (Harvard University Press 2007)

Becker C, The Declaration of Independence: A Study in the History of Political Ideas (2nd edn, Alfred A Knopf 1942)

Bentham J, An Answer to the Declaration of the American Congress (London 1776), reproduced in Armitage D (ed.), The Declaration of Independence: A Global History (Harvard University Press 2007) 173

Boyd JP, The Declaration of Independence: The Evolution of the Text as Shown in Facsimiles of Various Drafts by its Author, Thomas Jefferson (Princeton University Press 1945)

Boyd JP (ed.), The Papers of Thomas Jefferson, vol. 1, 1760-1776 (Princeton University Press 1950)

51 Hunt, 'Self-Evidence' (n. 2) 43.

52 See Hans Küng, Global Responsibility: In Search of a New World Ethic (Wipf \& Stock 2004).

53 Declaration Toward a Global Ethic (adopted 4 September 1993), part I, last para. <https:// www.weltethos.org > accessed 31 January 2019. For a discussion of Küng's work in the wider context of the global ethics literature, see Kimberly Hutchings, Global Ethics: An Introduction (Polity Press 2010) 11-19.

54 Declaration Toward a Global Ethic, part I, para. 4 (emphasis in the original). 
Gawalt GW, 'Drafting the Declaration' in Gerber SD (ed.), The Declaration of Independence: Origins and Impact (CQ Press 2002) 1

Hunt L, Inventing Human Rights: A History (WW Norton \& Co. 2007)

Hunt L, 'Humanity and the Claim to Self-Evidence' in Fassbender B and Traisbach K (eds),

The Limits of Human Rights (Oxford University Press 2019) 39

Hutchings K, Global Ethics: An Introduction (Polity Press 2010)

Irvin-Erickson D, Raphaël Lemkin and the Concept of Genocide (University of Pennsylvania

Press 2017)

Isaacson W, Benjamin Franklin: An American Life (Simon \& Schuster 2003)

Jayne A, Jefferson's Declaration of Independence: Origins, Philosophy and Theology (University Press of Kentucky 1998)

Jefferson T, A Summary View of the Rights of British America. Set Forth in Some Resolutions Intended for the Inspection of the Present Delegates of the People of Virginia now in Convention. By a Native, and Member of the House of Burgesses (Clementina Rind 1774) $<$ https://www.wdl.org/en/item/117/> (facsimile) and <https://founders.archives.gov/ documents/Jefferson/01-01-02-0090> accessed 31 January 2019

Jefferson T, 'Letter to the Mayor of Washington, DC, Roger C Weightman', 24 June 1826, in The Papers of Thomas Jefferson <http://founders.archives.gov/documents/Jefferson/9801-02-6179> accessed 31 January 2019

Küng H, Global Responsibility: In Search of a New World Ethic (Wipf \& Stock 2004)

Levinson S, 'Self-Evident Truths in the Declaration of Independence' (1979) 57 Texas Law Review 847

Lincoln A, Speeches and Writings 1832-1858 (Don E Fehrenbacher, ed., The Library of America 1989)

Lucas SE, 'The Stylistic Artistry of the Declaration of Independence' <http://www.archives. gov/founding-docs/stylistic-artistry-of-the-declaration> accessed 31 January 2019

Madison J, 'Notes of the Virginia Convention, May-June, 1776' in Library of Congress, James Madison Papers <https://www.loc.gov/exhibits/creating-the-united-states/battlejoined.html\#obj15> accessed 31 January 2019

Maier P, American Scripture: Making the Declaration of Independence (Alfred A. Knopf 1997)

Roosevelt E, 'Writing the Universal Declaration of Human Rights' in Fassbender B (ed.), Menschenrechteerklärung - Universal Declaration of Human Rights (Sellier European Law Publishers 2009) 31

Shain BA (ed.), The Declaration of Independence in Historical Context (Liberty Fund 2014)

White M, The Philosophy of the American Revolution (Oxford University Press 1978)

Wills G, Inventing America: Jefferson's Declaration of Independence (Doubleday \& Co. 1978)

Zuckert MP, 'Self-Evident Truth and the Declaration of Independence' (1987) 49 Review of Politics 319 


\section{The Limits \\ of Human Rights}

Edited by

BARDO FASSBENDER

KNUT TRAISBACH 